市内某養老院入寮者を対象として，昭和34年 8 月より 35 年 8 月までの 1 年間, 逐月基礎代謝定測定した。

1) 被検者は33年 7 月に行なわれた本学医学部による 㙟老院調查の結果に基く健康者を選出した。被験者は男 子9名 $(60$ 才〜 69 才 3 名，70才以上 6 名)，女子 10 名 $(60$ 才〜69才 3 名，70才以上 7 名）であった。

2）測定は早朝空腹時に当教室において行なった。測 定方法は Douglas-Bag法, 労研式大型分析器を使用し. 尿中窒素は Mikro-Kjeldahl 法を用いた。

3）定められた基整代謝実験諸条件に従い，算定にあ たって粗 R.Q.が原則とて $0.70 \sim 0.99$ の間のものを 採用した。

4） 1 時間体表面積当り基礎代謝の各月に扣引る平均 值を，曆生省標準値に比较すると，男子の 60〜69才の 組に执いては，12月之1月を除き，全般に低い値を示し 70才以上の組では全般に低い值を示した。また，女子で は 60〜69 才の組は全般に高い值を示し，70才以上の組 は全般に低い值を示した。月別平均推移は，男子全体で は 8 月以 $(28.2 \mathrm{cal})$ 最低値を示し，9月～11 月と增加 し，1月 $(32.5 \mathrm{cal})$ に最高值を示し， 2 月以後徐々に 減少し，夏期に至った。女子全体では 8 月（29.8 cal） に最低值を示し，9月〜12月と增加し，1月 $(32.6 \mathrm{cal})$ に最高值を示し，2月以後徐々に減少し夏期に至った。 また，年間平均値に刘し，男子で仿 8 月にー7.0\%，1 月に+8.3\%を示し，女子では 8 月に $-3.6 \% ， 1$ 月に $+5.5 \%$ を示した。年代別に見るに，男女とも60～69才 の組は70才以上の組に比し，いず狆も高い值を示した。 また，男女の基礎代謝に括ける各月平均值の差は明らか でなかつた。

5）尿水窒素排泟量，粗 R.Q. 非蛋白性 R.Q. の季 節的な変動は，男女とも明らかで7らかつった。

6）血压の変動は男子の最高血巨吾 8 月に低く，1月 に高い値を示す以外，特記すべき致動の様相は見られな かった。

\section{7. 機械化が労働量に及ぼす影響}

沼居幸吉, 安苳 清, 袩田 忠, 野村秀子

(学研生理)

日本の座業界も機珹化によってミ厘性の向上をみるに いたった。そして作盖者に筋的労倠から精神労動へと転 換し，エネルギー消費は目だって減少してきた。このこ とに関してはすでに学働科学誌上に発表しておいた。

しかし作業の全行程が僟械化された時は，このような 結果となるとしても，一部のみを機械化した時は必らず
しもこれと同稼だとはいい得ない。

いかにも機珹化された部分の外ついてい光ば，業種 にもよるが，機械化前に比しエネルギー代謝率は $1 / 2$ 人 1/4 に減少し, 生産性は2 45 倍と增大している。

これを別の面即ち職場全体の生産性加らみると，一部 の機珹化では前述のような生産性の向上とはならず，運 輸関係で 1.3 倍，採炭関係で 1.1〜1.4 倍, 製鉄王延関 係で 1.4〜1.7 倍の上沓に過ざない。

しかも機械化によつて作策者の平均学働量はみるべき ほどの減少を示していない。

生座性の问上をみない理由は機械化によって一部の生 産が増大しても，他の機栈化しない部分がこれと步調を 合わせ得ず，ために機械の長期運整を中止して機珹操作 者が筋的作業の手伝をせざるを得ないこと，または機械

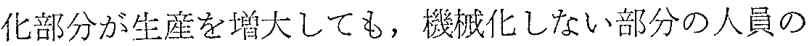
增大がないためなどが一応原因として考光られる。

学働量の減少しないのは前述の作珜形態をとる場合や 機珹化のため人員の減少や，または機械化によって機械 化しない部分の労動量の增大など，これらの理由によつ て全行程の平均労慟量としては隇少となり得ないもので あるら。

\section{8. 自動車タイヤ製造工程の学働量について}

宫川俊介，下村博之

（ブリジストンタイヤ久留米病院）

自動車タイヤ工場に和ける基本製造工程は精練，圧延 裁断, 張付, 加硫, 仕上及びチユーブに大別されるが，従 来よりこの種工程の労衝量に関する知見はきわめて少な い。演者らは過去数年にわたり，BS 久留米工場従業員 と刘象として，タイヤならびにチユーブ製造工程の労働 量を測定し，あわせて各工程間の作業強度を比較検討し てきたので，その成積について一括報告する。

測定方法は Douglas Bag を用い，ガス分析は労研式 大型分析器を使用した。測定成積の概要はつぎの如くオ ある。

1）精練は全工程の平均 RMR 5.0, 毎分時消費 Cal 6.6 で, 同工程作萻別の作業強度ではスモーク截断, タ ーレツト脚はカーボン投入，プレンダー薬品配合，22时 ロールに比してはるかに大である。

2) 圧延では全工程の平均 RMR 3.7, 毎分時 消費 Cal 4.6 となり, 作業別にはデッピング段取, 截断ジョ イント，4本カレンダー，トレツド押出の各工程間に有 意差を認めない。

3) 張付工程の平均 RMR は 4.0 4.5 で熟練工と 


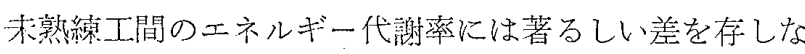
w。

4) マクニール加硫工程では平均 RMR 4.7, 每分時 消費Cal 6.2 を示し, 旧式のオートクレーブ加琉のRMR 4.8〜5.1 に比してやや小である。

5) チューブは全工程の平均 RMR 3.2, 每分洔消蕒 Cal 4.3 で同工程作業别の作業強度はタルク掂，押出の 順に大となり，チニーブヒーター加硫は最も小であっ た。

\section{9. 健康者の換気機能に関する研究}

川森正夫，览自五郎（群馬大公衛）

$13.5 l$ 型レスピロメーターにる各種呼吸機能の正常值

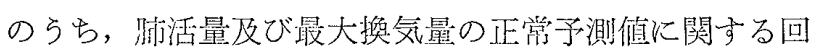
掃方程式は，研究者により备自異なり，正常の範囲を沃 定し難い現状である。この原因として, 異なる計器によ る特性の相異, 被検者の種類, 检查の技術的な倩, 等が 考壳られるが，とくに被検者については，どのような標 本を選定したかルより，検查内容の理解の程度が，最大 能力の発揮如何に影響を及洼すものと思われる。今回の 被検者は年令 20 才から45 才亦での陸上自衛豚員 200 名 及び中高等学校体育職員約 20 名で，2段肺活量，1秒量， 最大换気量等を測定した。その結果，種々の問題に直面 したのは最大換気量であるが，Baldwin による13.5 $l$ 型 の回㷌方程式は，われわれの場合火は不適业之思われ る。また 1 分間の呼吸回数については，60〜80回位が邀 当であると考觉られているが，メトロノ一学使用し， 異なる二つの呼吸回数による結果を比較した。また 1 秒 量を43倍した值を最大換気量值として使用する場合があ るが，この点についても検討を加えた。

\section{〔産業疲労〕}

\section{0. 䇟電図周波数分析による筋疲労の判定}

小木和孝，袴田 忠(学研労働生理)

筋疲労にともなって表面導出筋電戍に徐波化と群化の おこることは，すでに知られているが、これを筋疲労の判 定に応用するため表面道出筋電図の周波数分析を扣こ ない,筋疲労にともなら徐波化の罡的な表示をこころみ， それと張力の低下，神経筋単位の発射間隔の分散の增大

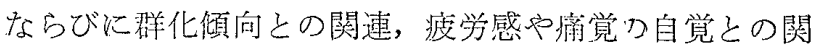
連をしらべた。

祘波数スペクトラムは筃によってかなりことなるが， $50 \mathrm{c} / \mathrm{s}$ 前後の優勢なものと比較的速波の特おいものとが
あり，一般に $40 \sim 100 \mathrm{c} / \mathrm{s}$ 前後の波が優勢である点は共 通している。

同一筋で同一と考えられる収縮状態をつつけていると

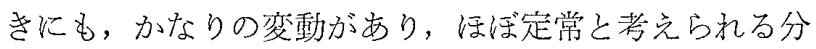
析結果をらるには，すくなくとも数秒程度の分析が必要 である。

電極条件によっても若干ことなり，電椣の位置や大き さなどによる差がみられるので，電極条件を一定にする 必要がある。

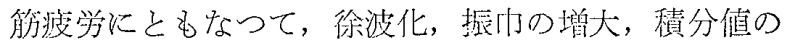
增大，および群化が文られるが，いずれの筋でも，とく に $40 \mathrm{c} / \mathrm{s}$ 以下の徐波の增大と, $100 \mathrm{c} / \mathrm{s}$ 前後あるいはそ れ以上の速波の減少の傾向は, 杵疲労の進行之よく一致 する。

以上のことから， $100 \mathrm{c} / \mathrm{s}$ 前後ないし $200 \mathrm{c} / \mathrm{s}$ 前後ま でをいくつかの䦌波数带域にわけて筇㻨図の分析・積分 を拈こならことによつて，筋疲労をあらわし，その星的 判定に応用することができる。

\section{1. 集中維持機能に関する研究 (II)

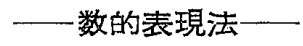

助川秀弥，高桑栄松（北大衛生） 集中維持機能表現法が，心的箘張乃至は注意集中能を 適確に把握し，嗵性検查あるいは㾜労判定に利用し得る ことは，すで前学会に氺いて発表したが，我々はさら にこれに対する数的表現を誠みた。

すなわら，描記された連続垪線 (Original Wave)に ついて，照準が正しく中心を指向した場合に得られるレ ベルを 0 とし，以下，照準の外れる度合に従って，10の均 等な段階を設け，それらに基き $0 ， 1 ， 2 ， 3 ， \cdots \cdots 10$ の值 を定めた。かくして得られた值を移動平均法により処理 して，標集化曲線を得た。

この標準化所線の淓型に基き模型的にユニツト階段を 定め, その階段数によって数型に分類した。さらに各二 ニツト階段についてのレベルを示すとともに，それらの 平均を求め，これを平均レベルとした。

この数的表現法により，平常㭙に和ける型と平均レべ ルが，種ふの傎倨にともない，いかに変化するかを数的 に表現することが可能なのである。

そして我及は，某銀行の眭間外特殊勤務に括汗万職員 の生体反忘を，集中恃㙨能表現法及び各種機能倹查法に より迫求した。 